\title{
Set Up Time Reduction Using Single Minute Exchange of Dies (SMED) and 5S: A Case Study
}

\author{
Johan K. Runtuk* ${ }^{1}$, Nathania Sembiring ${ }^{1}$ \\ ${ }^{1}$ Fakultas Teknik, Program Studi Teknik Industri, Universitas Presiden \\ Jl. Ki Hajar Dewantara, RT.2/RW.4, Mekarmukti, Kec. Cikarang Utara \\ Kabupaten Bekasi, Jawa Barat 17530 \\ Email: johan.runtuk@president.ac.id
}

\begin{abstract}
Manufacturing excellence represents the goal for every manufacturing industry all around the world. Reducing waste could help achieve manufacturing excellence since waste could happen in every manufacturing industry. As one of the foods and beverages industry, PT. MNO also focuses on reducing waste in the production process, especially in the filling department. Similar to other departments, the filling department also has planned and unplanned stoppages. As one of the planned stoppages, the setup activities represent one of the highest waste contributions in the filling department. Therefore, PT. MNO can reduce the setup time using the Single Minute Exchange of Dies (SMED) and 5S method. Then, the Overall Equipment Effectiveness (OEE) calculation can show the differences between filling machine productivity before and after implementation of the Single Minute Exchange of Dies (SMED) and 5S method. As a result, the setup time is reduced from 34 minutes to 13 minutes by using the Single Minutes Exchange of Dies (SMED) method implementation. After the $5 \mathrm{~S}$ method implementation, the setup time becomes 10 minutes. The Overall Equipment Effectiveness (OEE) calculation result shows better productivity after SMED and 5S method implementation in the filling department by the increasing OEE rate from $76 \%$ to $78 \%$.
\end{abstract}

Keywords: Setup, waste, planned stoppages, Single Minute Exchange of Dies (SMED), 5S, Overall Equipment Effectiveness (OEE).

\section{ABSTRAK}

Keunggulan manufaktur menjadi tujuan setiap industri manufaktur di seluruh dunia. Mengurangi waste dapat membantu mencapai keunggulan manufaktur, karena waste dapat terjadi di setiap industri manufaktur. Sebagai salah satu industri makanan dan minuman, PT. MNO juga fokus mengurangi waste dalam proses produksi, terutama di departemen filling. Serupa dengan departemen lain, departemen filling juga memiliki penghentian terencana dan tidak terencana. Sebagai salah satu penghentian yang direncanakan, kegiatan setup merupakan salah satu kontribusi waste tertinggi di departemen filling. Oleh karena itu, PT. MNO dapat mengurangi waktu setup menggunakan metode Single Minute Exchange of Dies (SMED) dan 5S. Kemudian, perhitungan Overall Equipment Effectiveness (OEE) dapat menunjukkan perbedaan antara produktivitas mesin filling sebelum dan sesudah penerapan Single Minute Exchange of Dies (SMED) dan metode 5S. Hasilnya, waktu setup berkurang dari 34 menit menjadi 13 menit dengan penerapan metode Single Minutes Exchange of Dies (SMED). Setelah penerapan metode 5S, waktu setup menjadi 10 menit. Hasil perhitungan Overall Equipment Effectiveness (OEE) menunjukkan produktivitas yang lebih baik setelah penerapan metode SMED dan $5 \mathrm{~S}$ di departemen filling dengan meningkatkan tingkat OEE dari $76 \%$ menjadi $78 \%$.

Kata kunci: Setup, waste, planned stoppages, Single Minute Exchange of Dies (SMED), 5S, Overall Equipment Effectiveness (OEE).

\section{Introduction}

MNO Company is one of the companies that produce food and beverage products. Based on the company, stoppages are categorized into two types: unplanned stoppages and planned stoppages. 
From the word unplanned and planned, the waiting process is differentiated with the one that occurs suddenly and the other one is the waiting that is already scheduled. Based on the whole company manufacturing process, the highest number of waiting waste occurs in filling machines, especially for the planned stoppages with $67 \%$ compared with the $33 \%$ for the unplanned stoppages.

The high rate of planned stoppages in the filling machine creates a minor loss to MNO Company. Planned stoppages that happen in the filling machine are differentiated into several types of stoppages. The most significant contribution of planned stoppages is $48 \%$ comes from setup time or line preparation time. The next is $34 \%$ of cleaning inspection and lubrication process, $19 \%$ of operational stoppages, $3 \%$ of meals or break, $2 \%$ of change over time, and the last $1 \%$ of planned maintenance. The highest contributor, which is the setup time, becomes the most concern stoppages in this case. The setup time takes too long to finish the activities, which actually, several activities can be reduced. One of the methods that can be used to reduce setup is the Single Minutes Exchange of Dies.

The single Minutes Exchange of Dies (SMED) method is a quick changeover technique. The SMED method applies to setup times. When setup times are too high, the manufacturing company needs to produce more lots and stocks, which means the production cost will increase (Shingo, 1985). SMED method has been applied all over the years with several implementation studies in several different processes, such as mold industry, pharmaceutical industry, and several more manufacturing industries (Simões \& Tenera, 2010). $5 \mathrm{~S}$ is one lean manufacturing method in reducing waste (Agrahari et al., 2015). 5S will organize the workplace to create a better flow of the production activities in the workplace. When the workplace condition is already cleansed and organized in the right place, it helps the worker conduct the activities more effectively.

As manufacturing excellence aims to create an excellent industry, there will be several obstacles that people need to face. The research was conducted to focus on the current problem that occurs, which is setup time. Reducing the setup time was the best solution to solve the current problem, but the specific method to solve the problem must be determined beforehand.

The improvement of setup time might increase the productivity of the machine. Overall Equipment Effectiveness (OEE) calculations are the tools to calculate the productivity of the machine. There are three primary rates in OEE which are availability, performance, and quality. The availability calculation is related to setup time, changeover time, unplanned maintenance, process failure, etc. The performance calculation is related to the minor stoppages, while the quality rate is related to the defect. The difference in setup time will impact the machine's productivity, which is shown in the calculation of the availability rate. Then, the calculation of OEE will show the productivity difference before and after SMED and $5 S$ method.

\section{Methods}

The data gathered in this research will be analyzed and calculated using several methods: Single Minute Exchange of Dies (SMED), 5S, and Overall Equipment Effectiveness. There are several data collection tools, including spaghetti diagram and histogram that employed in this research. First, the analysis is done by using the Single Minutes Exchange of Dies (SMED) method. Then, it is continued by the implementation of the $5 \mathrm{~S}$ method. The analysis of the Single Minutes Exchange of Dies (SMED) method consists of four steps: internal and external activities are not differentiated, separate internal and external activities, convert internal and external activities, and streamline internal activities. The $5 \mathrm{~S}$ method help to streamline the remaining internal activities to make the internal activities more effective than before. Finally, OEE calculation is conducted to compare the effectiveness of the machine before and after SMED and $5 \mathrm{~S}$ implementation.

\subsection{Single Minute Exchange of Dies (SMED)}

The Single Minute Exchange of Die (SMED) method was developed in 1950 by Ohno at Toyota. Toyota has a problem with the high inventory cost for the vehicle because reducing production loss was to reduce setup time. Then, Ohno wants to develop a system that can exchange dies in a fast and 
straightforward way. The phrase "single minutes" does not mean all the time must become one minute, but it means that the time must become single-digit minutes or less than ten minutes (Jebaraj Benjamin et al., 2013). The primary purpose of SMED is to reduce setup time on a machine. SMED is also called a quick change over of tools.

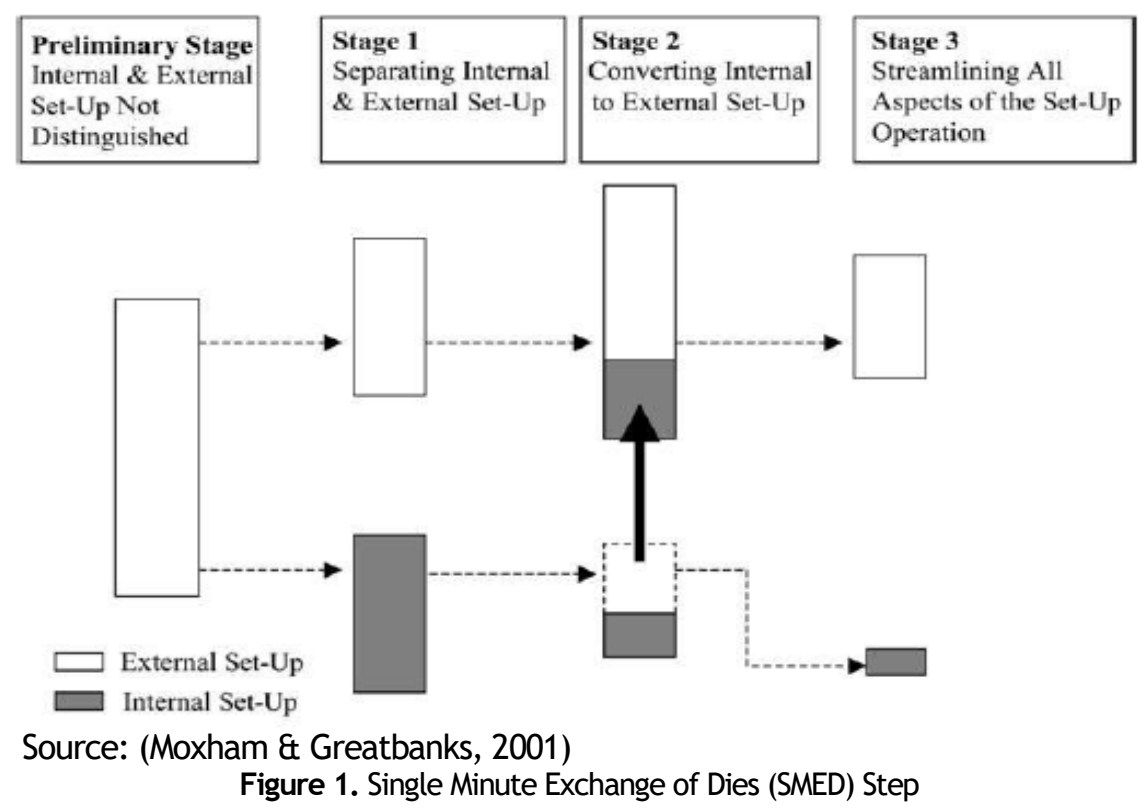

There are two kinds of setup, namely internal and external setup (Shingo, 1985). Internal setup is the activities that can be done when the machine is in idle condition or stop. External setup is the activities that can be done when the machine is running, before or after the machine is running. Based on figure 1, there are four stages for the Single Minute Exchange of Dies (SMED) method.

- Internal and External Setup are not differentiated - This phase is done by gathering all the data. The data about all activities classified from the beginning until the end are related to the setup problem. Besides that, the duration of each activity from the beginning until the end also must be collected. There will be other particular factors that affect the activities that must be concerned. By observing, it can show the critical part that reduces the efficiency of setup time.

- Separate the Internal and External activities - To help people to separate the internal and external activities, people can try to think, "Do these activities must be done when the machine is stopped? Can this activity be done when the machine is running?" It helps to differentiate whether the activity is internal or external. SMED usually uses three techniques for this step: checklist, function checks, and improved transport dies and other parts. Check all the internal and external activities, explain the function for all the operators, and improve the transportation tools.

- Convert Internal to External Activities - After internal and external are already classified, convert or shift internal activities to external activities must be done to achieve the goal of single-minute setup time. This step in SMED aims to identify whether the activities can be done during the machine running. It may lead to a reduction in several amounts of setup time. Converting internal to external activities can reduce the setup time a lot since the several activities that are all done when the machine runs are converted into activities done when the machine is running. The total time of machine stop or idle is reduced. Within this step, the automation of operations happens, and also the utilization of different tools.

- Streamline the remaining Internal Activities - After converting internal into external activities, these steps help reduce the remaining time of the internal activities that need to be done to achieve the goal of SMED, which is under 10 minutes.[3] A simple example to eliminate more setup time is relocating parts and materials to reduce the distance. When the activities need to take a long walk, the position can be adjusted by changing the production floor's layout. Relocating the parts and material also means that the layout of the production floor needs to be improved. 


\section{2. $5 \mathrm{~S}$}

$5 S$ originated from the Japanese manufacturing industry in 1950. In 1980, the $5 \mathrm{~S}$ method became more famous since many manufacturing industries started applying the $5 \mathrm{~S}$ methodology. $5 \mathrm{~S}$ stands for SEIRI, SEITON, SEISO, SEIKETSU, and SHITSUKE (Sekine \& Arai, 2017). The 5 S uses "Can see, Can take out, Can return" philosophy to improve the workplace (Ishijima et al., 2016). $5 \mathrm{~S}$ also becomes a simple strategy that the company can clean the shop floor, but it can develop into a better standard of workplace practices.

Table 1. 5S Explanation

\begin{tabular}{|l|l|l|l|l|}
\hline & Japanese & \multicolumn{1}{|c|}{ English } & Kiswahili & \multicolumn{1}{c|}{ Meanings } \\
\hline \hline S1 & Seiri & Sort & Sasambua & $\begin{array}{l}\text { Remove unused items from your workplace. This step } \\
\text { will also help to identify what is missing from your } \\
\text { workplace }\end{array}$ \\
\hline S2 & Seiton & Set & Seti & $\begin{array}{l}\text { Organize everything needed in proper order for more } \\
\text { accessible work. This step is based on finding efficient } \\
\text { and effective storage of necessary items. The setting of } \\
\text { necessary items can save time and energy when looking } \\
\text { for something }\end{array}$ \\
\hline S4 & Seiketsu & Standardize & Sanifisha & $\begin{array}{l}\text { Maintain a high standard of cleanliness of the } \\
\text { workplace, tools and equipment. This step will create } \\
\text { ownership of infrastructure, equipment and tools, and } \\
\text { enable identification of any abnormality of } \\
\text { infrastructure, equipment or tools }\end{array}$ \\
\hline S5 & Shitsuke & Sustain & Shine & $\begin{array}{l}\text { Maintain an environment share S1 to S3 are } \\
\text { implemented in the same manner throughout the } \\
\text { organization }\end{array}$ \\
\hline
\end{tabular}

When $5 \mathrm{~S}$ is integrated with the management system, it will improve productivity and even quality of delivery services and safety. $5 \mathrm{~S}$ can also integrate with other improvement methods to reduce waste in the manufacturing industry. With the successful outcome that several companies already got by implementing the $5 \mathrm{~S}$ methodology, $5 \mathrm{~S}$ becomes an effective tool to achieve the organization's goal.

\subsection{Overall Equipment Effectiveness (OEE)}

Overall Equipment Effectiveness or can be called OEE, was proposed by Nakajima in late 1980. OEE is a method used for measuring the performance of equipment or machine as part of Total Productive Maintenance (TPM) implementation. The objective of Overall Equipment Effectiveness (OEE) is to measure and investigate the overall performance, which might be a disturbance in the manufacturing process. OEE has three factors of performance measurement: availability, performance, and quality, which will be used for OEE calculation in rating the effectiveness of the machine or equipment (Jonsson \& Lesshammar, 2005).

a. Availability rate shows the availability of the machine during the production process (see Equation (2) and (3)). Loss in availability means the downtime loss of a machine, including breakdowns, setup time, and adjustment. The availability rate is related to unplanned stoppages and planned stoppages. Planned stoppages for this calculation include the setup or line preparation time and also the changeover time. Unplanned stoppages come from the breakdown time.

$$
\begin{aligned}
& \text { Availability rate }=\frac{\text { Operating Time }}{\text { Loading Time }} \times 100 \% \\
& \text { Availability rate }=\frac{\text { Loading Time }- \text { Downtime }}{\text { Loading Time }} \times 100 \%
\end{aligned}
$$

Loading time can be calculated by the total time the machine can operates or runs during a particular time. For example, if the OEE calculation is in one month, the loading time is the total machine time that 
can run in a month. The calculation of operating time is loading time minus downtime loss. Downtime loss can be calculated from the total unplanned and planned stoppages that have been mention before, which are set up or line preparation time, change over time, and breakdown time. Then, the calculation for availability rate is operating time divided by loading time.

b. Performance rate shows the performance of the machine in performing the production process (see Equation (3)). Speed loss is the OEE loss category in the performance rate and includes small stops and speed reduction. Performance rate is related to minor stoppages that happen during the production process and the operating time similar to the previous discussion.

Performance rate $=\frac{\text { Net Operating Time }}{\text { Operating Time }} \times 100 \%$

The performance loss can be taken from the sum of minor stoppages that happen during the production process. Net operating time is obtained by subtracting loading time with performance loss. The result of the performance rate comes from the net operating time divided by operating time.

c. Quality rate shows the quality-related due to the result of the production process. Quality loss includes start-up rejects and production rejects. The quality rate is related to the defect and the number of items produced during the production process as shown in Equation (4).

$$
\text { Quality rate }=\frac{\text { Processed Amount }- \text { Defect Amount }}{\text { Processed Amount }} \times 100 \%
$$

The total amount can be produced during the production process, while the defect amount is the total number of defects that occur during the production process. Then, the quality rate is processed amount minus defect amount and the result will be divided with the processed amount.

d. Overall Equipment Effectiveness (OEE) rate is the overall rate calculation that shows the effectiveness of the machine. Overall Equipment Effectiveness (OEE) rate is related to availability, performance, and quality rate as seen in Equation (5).

$$
\text { OEE Rate }=(A \times P \times Q) \times 100 \%
$$

Overall Equipment Effectiveness (OEE) rate can be calculated by multiplying the availability, performance, and quality rate and the result is in percentage. The higher the OEE rate, the management of the production process in the manufacturing process is already effective and efficient. With the lower OEE rate, the production process is ineffective and needs several improvements to increase the OEE rate.

\section{Result and Discussion}

The data already gathered will be analyzed furthermore. The result will show the difference between the setup time before and after Single Minute Exchange of Dies (SMED) and $5 \mathrm{~S}$ implementation. The Overall Equipment Effectiveness also shows the productivity difference before and after SMED and $5 \mathrm{~S}$ implementation.

\subsection{SMED and 5S}

In this research, there are several improvements happen which are the reduction of setup activities. Before the improvement of Single Minute Exchange of Dies (SMED), the actual setup activities are eight activities in total with 34 minutes to finish the setup activities shown in table 2.

Table 2 shows the overall setup activities of the filling machine area, including the time start, time stop, and total time needed to conduct each activity. The total time needed to conduct the setup activities in the filling machine is $\mathbf{3 4}$ minutes, with eight different activities.

Based on Single Minute Exchange of Dies (SMED), four internal activities can be done when the machine runs: cleaning environment, input data SAM/SAP, cut open rework and Shift Hand-Over. Those activities will be converted to external activities to reduce the setup time, which is the internal activities. Table 3 will show the remaining internal activities in the filling machine. 
Table 2. Setup Activities in Filling Machine

\begin{tabular}{|c|c|c|c|c|}
\hline $\mathrm{NO}$ & Activity & Time Start & Time Stop & Total Time \\
\hline $\mathbf{A}$ & \multicolumn{3}{|l|}{ Checking Metal Detector } & \\
\hline 1 & Record Counter Metal Detector & 0:00:00 & 0:01:00 & 0:01:00 \\
\hline \multirow[t]{2}{*}{2} & Verified positive sample metal detector & $0: 01: 00$ & $0: 02: 00$ & 0:01:00 \\
\hline & & & & 2 minutes \\
\hline $\mathbf{B}$ & \multicolumn{3}{|l|}{ Cleaning Environment } & \\
\hline 3 & Take Cleaning Tools & $0: 02: 00$ & $0: 04: 00$ & $0: 02: 00$ \\
\hline 4 & Cleaning floor below the machine & 0:04:00 & 0:07:00 & 0:03:00 \\
\hline \multirow[t]{2}{*}{5} & Tidy Up Cleaning Tools & 0:07:00 & 0:09:00 & 0:02:00 \\
\hline & & & & 7 minutes \\
\hline $\mathbf{C}$ & \multicolumn{3}{|l|}{ Cle aning Machine } & \\
\hline 6 & Take Cleaning Tools & 0:09:00 & $0: 11: 00$ & 0:02:00 \\
\hline 7 & Cleaning Horizontal Seal Bar & $0: 11: 00$ & $0: 11: 30$ & 0:00:30 \\
\hline 8 & Cleaning Vertical Seal Bar & $0: 11: 30$ & $0: 12: 00$ & 0:00:30 \\
\hline 9 & Cleaning Colar & $0: 12: 00$ & $0: 12: 20$ & 0:00:20 \\
\hline 10 & Cleaning Knife Jaw & $0: 12: 20$ & $0: 12: 40$ & 0:00:20 \\
\hline 11 & Cleaning Cover Acrylic & $0: 12: 40$ & $0: 13: 00$ & $0: 00: 20$ \\
\hline 12 & Cleaning Conveyor Plat & 0:13:00 & $0: 13: 30$ & 0:00:30 \\
\hline 13 & Cleaning Conveyor Belt & $0: 13: 30$ & $0: 14: 00$ & 0:00:30 \\
\hline \multirow[t]{2}{*}{14} & Tidy Up Cleaning Tools & $0: 14: 00$ & $0: 16: 00$ & $0: 02: 00$ \\
\hline & & & & 7 minutes \\
\hline D & \multicolumn{3}{|l|}{ Input Data SAM } & \\
\hline 15 & Pre-input data SAM & $0: 16: 00$ & $0: 18: 30$ & $0: 02: 30$ \\
\hline 16 & Collect sheet report & $0: 18: 30$ & $0: 19: 00$ & $0: 00: 30$ \\
\hline \multirow[t]{2}{*}{17} & Input to computer & 0:19:00 & $0: 24: 00$ & 0:05:00 \\
\hline & & & & 8 minutes \\
\hline $\mathbf{E}$ & \multicolumn{3}{|l|}{ Take Sample for Bubble Test } & \\
\hline 18 & Take Sample for Bubble Test & $0: 24: 00$ & $0: 25: 00$ & 0:01:00 \\
\hline 19 & Waiting sampling result & $0: 25: 00$ & $0: 25: 40$ & $0: 00: 40$ \\
\hline \multirow[t]{2}{*}{20} & Report sampling & $0: 25: 40$ & $0: 26: 00$ & 0:00:20 \\
\hline & & & & 2 minutes \\
\hline $\mathbf{F}$ & \multicolumn{3}{|l|}{ Take Sample for Carbon Test } & \\
\hline 21 & Take Sample for Carbon Test & $0: 26: 00$ & $0: 27: 00$ & 0:01:00 \\
\hline 22 & Waiting sampling result & $0: 27: 00$ & $0: 27: 40$ & $0: 00: 40$ \\
\hline \multirow[t]{2}{*}{23} & Report sampling & $0: 27: 40$ & $0: 28: 00$ & 0:00:20 \\
\hline & & & & 2 minutes \\
\hline $\mathbf{G}$ & \multicolumn{3}{|l|}{ Cut Open Rework } & \\
\hline \multirow[t]{2}{*}{24} & Cut Open Rework & $0: 28: 00$ & $0: 31: 00$ & 0:03:00 \\
\hline & & & & 3 minutes \\
\hline $\mathbf{H}$ & \multicolumn{3}{|l|}{ SHO Update } & \\
\hline \multirow[t]{2}{*}{25} & SHO Update & $0: 31: 00$ & $0: 34: 00$ & 0:03:00 \\
\hline & & & & 3 minutes \\
\hline \multicolumn{4}{|c|}{ TOTAL } & 34 minutes \\
\hline
\end{tabular}


Table 3. Setup Activities in Filling Machine

\begin{tabular}{|c|c|c|c|}
\hline $\mathrm{NO}$ & Activity & $\begin{array}{c}\text { Time } \\
\text { (minute) }\end{array}$ & Explanation \\
\hline $\mathbf{A}$ & \multicolumn{3}{|l|}{ Checking Metal Detector } \\
\hline 1 & Record Counter Metal Detector & 1 & $\begin{array}{l}\text { metal detector test in metal detector } \\
\text { equipment }\end{array}$ \\
\hline 2 & Verified positive sample metal detector & 1 & verified the result of metal detector \\
\hline $\mathbf{C}$ & \multicolumn{3}{|l|}{ Cleaning Machine } \\
\hline 6 & Take Cleaning Tools & 2 & $\begin{array}{l}\text { take blue cleaning tools to clean the } \\
\text { machine }\end{array}$ \\
\hline 7 & Cleaning Horizontal Seal Bar & \multirow{2}{*}{1} & \multirow{2}{*}{ clean horizontal and vertical seal bar } \\
\hline 8 & Cleaning Vertical Seal Bar & & \\
\hline 9 & Cleaning Colar & \multirow{3}{*}{1} & \multirow{3}{*}{ clean colar, knife jaw, cover acrylic } \\
\hline 10 & Cleaning Knife Jaw & & \\
\hline 11 & Cleaning Cover Acrylic & & \\
\hline 12 & Cleaning Conveyor Plat & \multirow{2}{*}{1} & \multirow{2}{*}{ clean conveyor plat and belt } \\
\hline 13 & Cleaning Conveyor Belt & & \\
\hline 14 & Tidy Up Cleaning Tools & 2 & $\begin{array}{l}\text { re-store blue cleaning tools to } \\
\text { previous place }\end{array}$ \\
\hline $\mathbf{E}$ & \multicolumn{3}{|l|}{ Take Sample for Bubble Test } \\
\hline 18 & Take Sample for Bubble Test & 1 & $\begin{array}{l}\text { take the product of filling machine to } \\
\text { bubble sample test equipment }\end{array}$ \\
\hline 19 & Waiting sampling result & \multirow{2}{*}{1} & \multirow{2}{*}{$\begin{array}{l}\text { wait the result of bubble test and } \\
\text { record the result }\end{array}$} \\
\hline 20 & Report sampling & & \\
\hline $\mathbf{F}$ & \multicolumn{3}{|l|}{ Take Sample for Carbon Test } \\
\hline 21 & Take Sample for Carbon Test & 1 & $\begin{array}{l}\text { take the product of filling machine to } \\
\text { carbon sample test equipment }\end{array}$ \\
\hline 22 & Waiting sampling result & \multirow{2}{*}{1} & \multirow{2}{*}{$\begin{array}{l}\text { wait the result of carbon test and } \\
\text { record the result }\end{array}$} \\
\hline 23 & Report sampling & & \\
\hline TO' & TAL & 13 & \\
\hline
\end{tabular}

After Single Minute Exchange of Dies (SMED) improvement, four internal activities are converted to external activities, and the rest remaining activities become the internal activities. Then, the total time needed to perform the remaining internal activities are 13 minutes.

$5 S$ implementation will help improve the filling machine area, which means removing or replacing the unneeded items. The other improvement might be to replace the location of the needed items to the appropriate location to help the operator perform a more effective movement in setup activities. The unneeded items that are not useful for setup activities are the tip table. Figure 2 shows the initial and after improvement layout design of the filling machine after $5 \mathrm{~S}$ method implementation.

The initial and after improvement layout design of filling machine are shown in figure 2. The next improvement is to replace the location of the SAM/SAP table with the nearest place to the filling machine and replace the location of cleaning tools (red and blue). The SAM/SAP table is replaced from 10 meters away from the machine to only 5.6 meters, while the red and blue cleaning tools are reduced from 7 meters to 5.6 meters away from the filling machine.

The table 4 and 5 show the result of Single Minute Exchange of Dies (SMED) and $5 S$ implementation and will be compared with the actual setup activities before the new implementation. The table includes the time for each setup activity, and also, the operator took the distance in performing the setup activities. Table 4 shows the result for internal activities or the activities done when the machine stops. 
Before

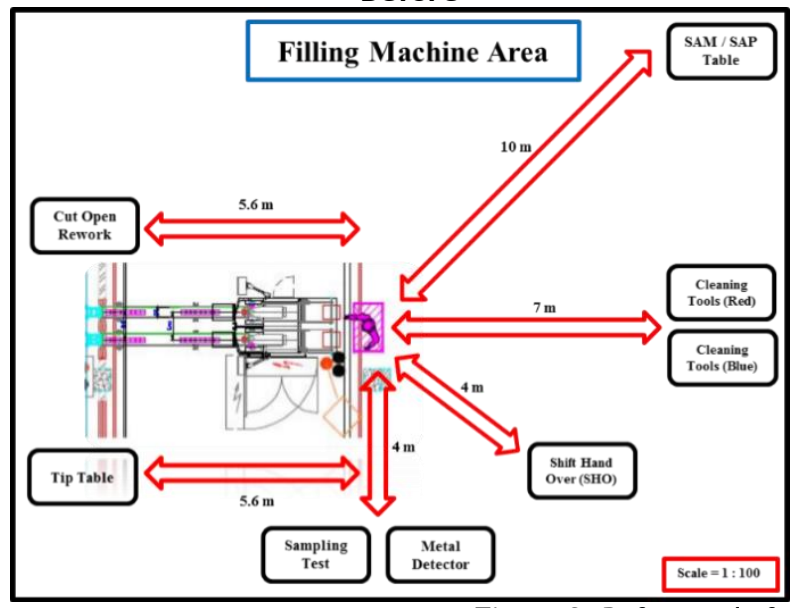

After

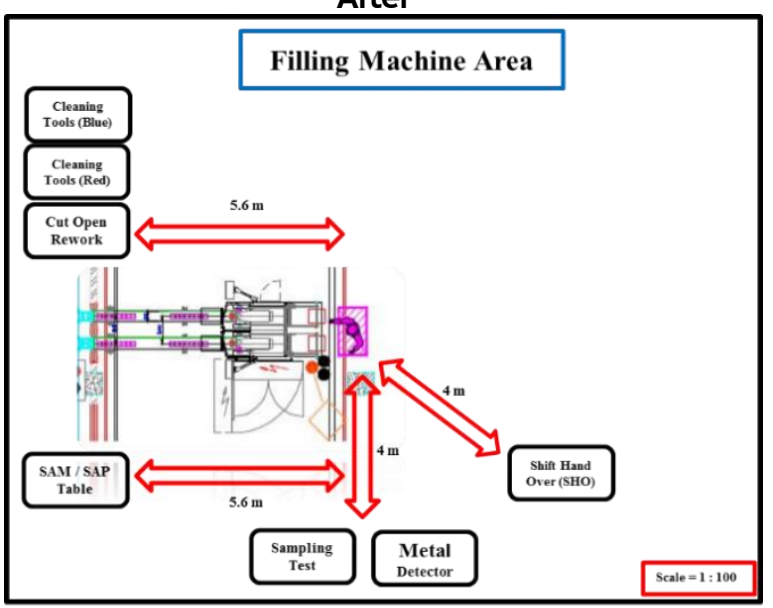

Figure 2. Before and after Filling Machine Layout

Table 4. Activities are done when the Filling Machine stops

\begin{tabular}{|c|c|c|c|c|c|}
\hline \multirow{2}{*}{ NO } & \multirow{2}{*}{ Activity } & \multicolumn{2}{|c|}{ Time (minute) } & \multicolumn{2}{|c|}{ Distance (meter) } \\
\hline & & Before & After & Before & After \\
\hline \multicolumn{6}{|c|}{ Activities done when the machine stops } \\
\hline \multirow[t]{4}{*}{1} & Checking Metal Detector & & & & \\
\hline & Record Counter Metal Detector & 1 & 1 & 1 & 1 \\
\hline & Verified positive sample metal detector & 1 & 1 & 4 & 4 \\
\hline & & 2 & 2 & 5 & 5 \\
\hline \multirow[t]{11}{*}{2} & Cleaning Machine & & & & \\
\hline & Take Cleaning Tools & 2 & 0.5 & 0 & 5 \\
\hline & Cleaning Horizontal Seal Bar & \multirow{2}{*}{1} & \multirow{2}{*}{1} & 7 & 2 \\
\hline & Cleaning Vertical Seal Bar & & & 0 & 0 \\
\hline & Cleaning Colar & \multirow{3}{*}{1} & \multirow{3}{*}{1} & 2 & 1 \\
\hline & Cleaning Knife Jaw & & & 0 & 0 \\
\hline & Cleaning Cover Acrylic & & & 1 & 2 \\
\hline & Cleaning Conveyor Plat & \multirow{2}{*}{1} & \multirow{2}{*}{1} & 1 & 2 \\
\hline & Cleaning Conveyor Belt & & & 0 & 0 \\
\hline & Tidy Up Cleaning Tools & 2 & 0.5 & 7 & 3 \\
\hline & & 7 & 4 & 18 & 15 \\
\hline \multirow[t]{5}{*}{3} & Take Sample for Bubble Test & & & & \\
\hline & Take Sample for Bubble Test & 1 & 1 & 4 & 4 \\
\hline & Waiting sampling result & \multirow{2}{*}{1} & \multirow{2}{*}{1} & 0 & 0 \\
\hline & Report sampling & & & 4 & 4 \\
\hline & & 2 & 2 & 8 & 8 \\
\hline \multirow[t]{4}{*}{4} & Take Sample for Carbon Test & & & & \\
\hline & Take Sample for Carbon Test & 1 & 1 & 4 & 4 \\
\hline & Waiting sampling result & \multirow{2}{*}{1} & \multirow{2}{*}{1} & 0 & 0 \\
\hline & Report sampling & & & 4 & 4 \\
\hline & & 2 & 2 & 8 & 8 \\
\hline \multicolumn{2}{|c|}{ TOTAL } & 13 & 10 & 39 & 36 \\
\hline
\end{tabular}

Table 4 shows that the setup activities, which means the activities done when the machine stops, are reduced from 13 minutes to 10 minutes. The distance taken by the operator in performing the actual setup activities is 39 meters. After the Single Minute Exchange of Dies (SMED) and 5S implementation, the total distance taken is reduced become only 36 meters. The total reduction time for the setup activities is 3 minutes, while the total distance reduction is 3 meters in total. 
The following table will explain the external activities or the activities done when the machine runs. There are four external activities and include the following information: the time needed to perform the external activities and the total distance taken to perform the external activities before and after Single Minute Exchange of Dies (SMED) and $5 S$ implementation.

Table 5. Activities done when the Filling Machine runs

\begin{tabular}{|c|c|c|c|c|c|}
\hline \multirow{2}{*}{ NO } & \multirow{2}{*}{ Activity } & \multicolumn{2}{|c|}{ Time (minute) } & \multicolumn{2}{|c|}{ Distance (meter) } \\
\hline & & Before & After & Before & After \\
\hline \multicolumn{6}{|c|}{ Activities done when the machine runs } \\
\hline \multirow[t]{5}{*}{1} & Cleaning Environment & & & & \\
\hline & Take Cleaning Tools & 2 & 0.5 & 7 & 5 \\
\hline & Cleaning floor below the machine & 3 & 3 & 1 & 1 \\
\hline & Tidy Up Cleaning Tools & 2 & 0.5 & 7 & 5 \\
\hline & & 7 & 4 & 15 & 11 \\
\hline \multirow[t]{5}{*}{2} & Input Data SAM & & & & \\
\hline & Pre-input data SAM & 2.5 & 1.5 & 10 & 5 \\
\hline & Collect sheet report & 0.5 & 0.5 & 0 & 0 \\
\hline & Input to computer & 5 & 5 & 10 & 5 \\
\hline & & 8 & 7 & 20 & 10 \\
\hline \multirow[t]{2}{*}{3} & Cut Open Rework & 3 & 3 & 10 & 5 \\
\hline & & 3 & 3 & 10 & 5 \\
\hline \multirow[t]{2}{*}{4} & SHO Update & 3 & 3 & 8 & 10 \\
\hline & & 3 & 3 & 8 & 10 \\
\hline \multicolumn{2}{|c|}{ TOTAL } & 21 & 17 & 53 & 36 \\
\hline
\end{tabular}

Table 5 shows that the time needed to perform external activities before new improvement is 21 minutes, while after $5 \mathrm{~S}$ improvement, the total time taken becomes only 17 minutes. Besides that, the operator's movement in performing the external activities before the new improvement is 53 meters. After implementing the new improvement, the distance was taken by the operator only 36 meters. The total reduction is 4 minutes for the external time, while the total reduction for the distance is 17 meters.

\subsection{Overall Equipment Effectiveness (OEE)}

From April 2016 until June 2016, the number of unplanned stoppages and the planned stoppages is different. Then, the result for the OEE rate for each month also must be different. Overall Equipment Effectiveness (OEE) from April until June 2016 are summarized into one Pareto Chart shown in figure 2. The data is taken from the manual calculation about Overall Equipment Effectiveness (OEE) before and after SMED and 5S implementation).

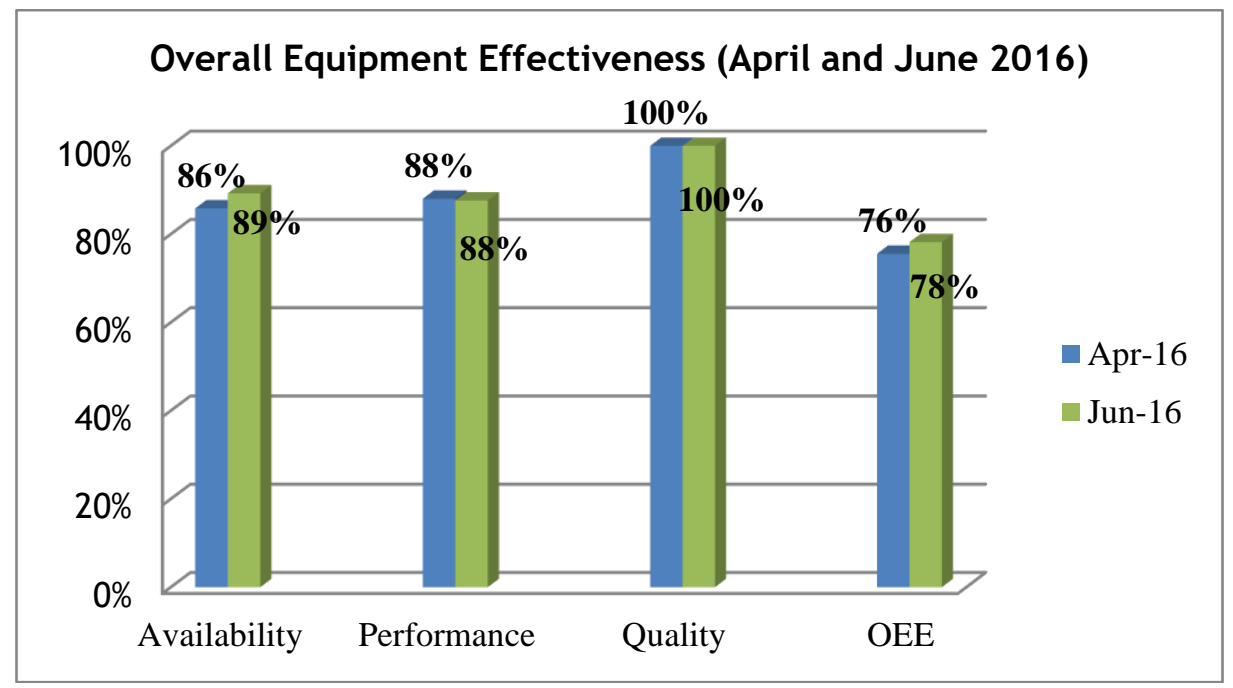

Figure 2. Precedence Diagram of Model A005TG2991ZJ Assembly Process 
The first rate is the availability rate which calculates the operating time divided by loading time. The calculation of availability rate includes the line preparation or setup time. The setup time before SMED method implementation is 34 minutes, while after SMED implementation, the setup time becomes 13 minutes. Then, after $5 \mathrm{~S}$ implementation, the setup time decreases more become 10 minutes. The availability rate is calculated based on the operating time divided by loading time. The operating time has decreased every month since April and June 2016 because the setup time is also decreasing. The availability rates from April and June 2016 are $86 \%$ and $89 \%$. The performance rate shows different results in the filling machine. The performance rate calculations are using the minor stoppages data from April and June 2016. The machine itself causes minor stoppages that happen in the filling machine. When the minor stoppages are high, the performance rate will be low because the performance rate calculation is based on the performance loss. The performance rate from May and June 2016 is $88 \%$ and $88 \%$. The quality rate for the entire month from May and June 2016 is $100 \%$. Then, the OEE rates are 76\% and 78\% from May until June 2016.

\section{4. Conclusion}

Based on the Single Minute Exchange of Dies (SMED) implementation, the setup time is reduced from 34 minutes to 13 minutes. Then, using the $5 \mathrm{~S}$ method reduces the setup time from 13 minutes into 10 minutes after implementing the $5 \mathrm{~S}$ method. The total reduction time before implementing Single Minute Exchange of Dies (SMED) and 5S implementation is 24 minutes, reducing from 34 minutes to 10 minutes of setup activities.

Based on the Overall Equipment Effectiveness (OEE) calculation, the difference of OEE rate is increasing from April to June $201676 \%$ to $78 \%$. The calculation of OEE includes the line preparation or setup time. Thus, the reduction of setup time influences the increase of the OEE rate. The OEE rate is increasing in PT. MNO, which means PT. MNO has good productivity than before.

\section{References}

1. Agrahari, R. S., Dangle, P. A., \& Chandratre, K. V. (2015). Implementation Of 5 S Methodology In The Small Scale Industry A Case Study. International Journal of Scientific \& Technology Research, 4(4), 180-187.

2. Ishijima, H., Eliakimu, E., \& Mshana, J. M. H. (2016). The " $5 S$ " approach to improve a working environment can reduce waiting time: Findings from hospitals in Northern Tanzania. TQM Journal, 28(4), 664-680. https://doi.org/10.1108/TQM-11-2014-0099.

3. Jebaraj Benjamin, S., Murugaiah, U., \& Srikamaladevi Marathamuthu, M. (2013). The use of SMED to eliminate small stops in a manufacturing firm. Journal of Manufacturing Technology Management, 24(5), 792-807. https://doi.org/10.1108/17410381311328016.

4. Jonsson, P., \& Lesshammar, M. (2005). of manufacturing performance measurement systems - the role of OEE. International Journal of Operations \& Production Management, 19(1), 55-78.

5. Moxham, C., \& Greatbanks, R. (2001). Prerequisites for the implementation of the SMED methodology: A study in a textile processing environment. International Journal of Quality and Reliability Management, 18(4), 404-414. https://doi.org/10.1108/02656710110386798.

6. Sekine, K., \& Arai, K. (2017). TPM for the Lean Factory. In TPM for the Lean Factory. https: / /doi.org/10.1201/9780203735336.

7. Shingo, S. (1985). A Revolution in Manufacturing: The SMED System. Productivity Press.

8. Simões, A., \& Tenera, A. (2010). Improving setup time in a press line - Application of the SMED methodology. In IFAC Proceedings Volumes (IFAC-PapersOnline) (Vol. 43, Nomor 17). IFAC. https://doi.org/10.3182/20100908-3-PT-3007.00065. 